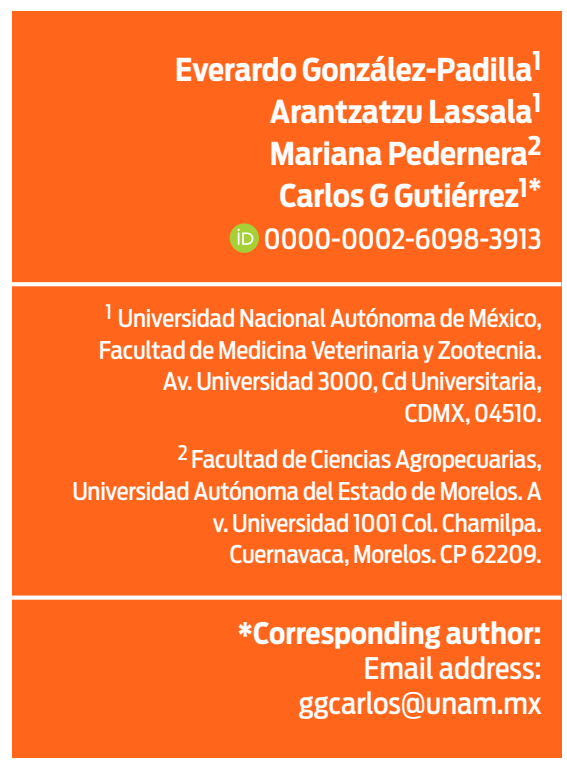

Accepted: $2019-08-27$ Published: 2019-09-30 Additional information and declarations can be found on page 16

(c) Copyright 2019 Everardo González-Padilla et al. open access $\boldsymbol{2}$



Distributed under Creative Commons CC-BY 4.0

\section{Cow-calf management practices in Mexico: Farm organization and infrastructure}

\section{Abstract}

Beef cattle breeding has developed in extensive grazing systems in Mexico, concerning the livelihood of over one million families and affecting the use of natural resources. The diversity of climate, region, land tenure, herd size and poverty level potentially influence livestock farming. To detect areas of opportunity in the use of human, animal and natural resources, and to determine the degree of technological penetration, a structured questionnaire was administered as personal interviews to 3280 producers. Over 50\% of farmers have an activity other than cattle breeding, mostly raising crops and other livestock. Weaned calves, primarily destined for the national market, are the foremost commercial product. Nevertheless, 20\% of farmers in the northern region export their calves. European X Zebu crossbred cattle are widespread (over $45 \%$ of operations), followed by Bos taurus taurus breeds (22\%). Criollo and predominantly Zebu cattle are present in $<15 \%$ of farms, and dairy breeds in $<5 \%$. Over $70 \%$ of producers declared to select animal breed based on productive traits and adaptability, even though only $52 \%$ have record-keeping systems. The customary method to register data is hand-written, and $<7 \%$ of producers use computers. Recorded information comprises data on reproduction (59.1\%), calves (44\%), herd health practices (32\%) and purchases and sales (28\%). Over 95\% of farmers identify animals by hot iron marks and National Individual Livestock Identification System (SINIIGA) ear tags. Close to 52\% of animal breeders do not receive technical advice. Finally, according to producers, the main constraints for farm growth and profitability were lack of access to credit, followed by low market value of their products and insufficient infrastructure.

Keywords: Record-keeping, animal identification, information sources, cow-calf operations, survey

\section{Cite this as:}

González-Padilla E, Lassala A, Pedernera M, Gutiérrez CG. Cow-calf management practices in Mexico: Farm organization and infrastructure. VetMéxOA. 2019;6(3). doi: 10.22201/ fmvz.24486760e.2019.3.677 


\section{Introduction}

Beef cattle breeding operations can be found throughout the Mexican territory, where they occupy more than 110 million ha. ${ }^{1-3}$ This undertaking directly impacts the livelihood and economic stability of over one million families ${ }^{4,5}$ and signifies an important part of their heritage and social identity. Cow-calf operations in Mexico comprise a wide array of producers, ranging from those that farm in communal land to those that lead the livestock export market.

Development of beef cattle breeding has answered to diverse sociopolitical, economic, and ecological circumstances in Mexico. The social demands formulated during the Mexican Revolution in the XX Century, encouraged the growth of grazing areas through land redistribution, establishment of communal properties, allocation of government owned land to usufructuary farmers (ejidos), and by the requirement imposed by the government that forced farmers to demonstrate an economic use of their private property. Migration of human populations from the North and Center to the Southeast of the country due to colonization processes, as well as to failed agricultural and forest extractive projects, also contributed to extensions of land ending up as pastures or abandoned plots with secondary growth of vegetation, where livestock breeding was the last viable endeavor. ${ }^{6}$

Beef cattle production units are hence found as extensive grazing systems that occupy a vast and valuable stretch of the Mexican territory, thus having an impact on the use of natural resources and affecting the quality and preservation of ecosystems. Consequently, a rational and sustainable exploitation, to maximize the economic and ecologic potentials of every region is currently sought. To make this possible, the diverse topographic conditions of the country need to be considered, since they affect climate and microclimate maps, and dictate the ecological settings that determine the availability of resources. In addition, cultural differences through geographic regions, land tenure status and even herd size must be considered, since they also affect management practices within production units.

The aim of this observational study was thus to characterize management practices of cow-calf operations through different regions, climates, herd sizes, land tenure types and poverty levels, to establish the state of technological penetration and to identify areas of opportunity to improve productivity and sustainability. Data were obtained through structured interviews administered directly to the farm owner or the person in charge of the operation. Fixed variables were established assuming a potential effect on the prevalence of management practices, however the magnitude, if present, was unknown.

More than 3000 cow-calf production units were included in this diagnostic survey. The results are shown as a series of five articles, which cover: (a) Farm organization and infrastructure, (b) Reproduction and breeding, (c) Environment and animal welfare, (d) Dual-purpose systems and (e) Specialized dairy production in pasture.

\section{Material and methods}

Management practices and use of technology in grazing cattle production units in Mexico were characterized by a structured questionnaire that gathered descriptive information related to farm organization, broad management of the herd, 
occurrence of infrastructure, feeding practices, health and well-being, environmental management practices, reproductive management, handling of calves, dual-purpose systems, and a section devoted to specialized dairy production in pasture.

The questionnaire was adapted from the one used by the United States Department of Agriculture (USDA) to characterize beef-calf management practices in the United States of America, ${ }^{7}$ considering adjustments and suggestions offered by experienced academics, technicians and farmers from different regions of Mexico. Licensed veterinarians or technicians administered eighty-two structured questions as personal interviews to farm owners or managers, directly in the production units.

The number of questionnaires to be administered countrywide was calculated by the following formula:

$$
\mathrm{n}=\frac{\mathrm{z}^{2} p q}{\mathrm{~d}^{2}}
$$

The confidence level (z) was set at 95\%, with a probability (p) of 50\% and an estimated error (d) of $5 \%$.

A correction for finite populations was applied to the calculated sample size, considering the total number of productive units registered in the 2009 PROGAN census, ${ }^{8}$ using the following formula:

$$
\mathrm{n}_{\text {corr }}=\frac{n}{1+(\mathrm{n}-1 / \text { pob })}
$$

To determine the number of questionnaires to be completed per state within a region, the weighted corresponding percentage of the total productive units was considered.

The calculated number of questionnaires to be administered was 3158. In total 3311 questionnaires were completed, of which 31 were discarded due to answer discrepancies. Thus, the final database included information from 3280 operations.

\section{Statistical analyses}

Each possible option within a question was considered as a binary variable. When the question specified that a single response should be chosen, the frequency of a management practice was analyzed by REML. ${ }^{9}$ When the answer to the question indicated that more than one choice was allowed, each selection was analyzed separately by univariate analysis. The results are shown as least square means and standard error of the difference (sed). Differences are declared at $p<0.05$.

Fixed variables were considered as follows:

I Herd size: defined as small (up to 35 cows), medium (36 to 100 cows) and large (over 100 cows).

- Region: the country was arbitrarily divided in five regions according to their similarity in agro-ecological characteristics and geographical proximity, namely: North (Baja California, Baja California Sur, Chihuahua, Coahuila, Durango, Nuevo Leon, Sonora and Zacatecas); Center (Aguascalientes, Estado de Mexico, 
Guanajuato, Hidalgo, Puebla, Queretaro, San Luis Potosi and Tlaxcala); Pacific (Chiapas, Colima, Guerrero, Jalisco, Michoacan, Morelos, Nayarit, Oaxaca and Sinaloa); Gulf (Tabasco, Tamaulipas and Veracruz), and Peninsula (Campeche, Quintana Roo and Yucatan).

- Climate: classified as arid-semiarid, temperate, dry tropics and humid tropics, according to Garcia. ${ }^{10}$

- Poverty levels were defined following municipal categories set by the National Population Council ${ }^{11}$ as very low, low, medium, high and very high.

- Land-tenure type was declared by the producer as communal land, ejido and private property.

\section{Results and Discussion}

Of the 3280 surveyed farms, 2055 were reported as beef-producing units, 996 as dual-purpose (DP) operations and the rest (229) as either having both systems or specialized dairy production in pasture. Beef producing and dual-purpose systems were found throughout the country.

It is common for producers to combine cattle breeding with crop raising (40\%) and to a lesser extent, with keeping of other livestock (6\%). Indeed, cattle production units in Mexico commonly function as mixed systems, where a range of agricultural activities can occur simultaneously. In fact, $45 \%$ of cattle herds throughout the country consist of 10 cows or less, thus producers are compelled to diversify the use of their time in activities other than raising cattle (National Livestock Census, unpublished data). In addition, products obtained from crop-raising may be sold seasonally or used for animal feed. Moreover, almost $60 \%$ of the producers have an economic activity that is not linked to livestock breeding, and particularly so in regions with temperate climate. Conversely, 59\% of producers in the humid tropics devote their time exclusively to animal production. In addition, operations restricted to cattle production are more frequently found in municipalities with very low poverty level (46\%) and are more common among beef-cattle operations than amid units that work with dual-purpose cattle (Table 1). For general context, only 36.8\% of people employed in rural areas work in agriculture. ${ }^{12,13}$

Most cow-calf operations sell their product domestically $(95.8 \%$, sed $=0.6)$, either to local buyers or to middlemen, who then deliver animals to backgrounding or feedlot systems throughout the country. However, $20.8 \%$ of operations in the north of Mexico export their calves, in particular in production units that are located in areas that have achieved the sanitary status required by the USDA. Also, expressly in the north region of the country, the proportion of productive units that declare to export their calves increases as the size of the operation increases (small 8\%, medium 19.3\% and large 30.8\%; sed $=4.6$ ). Similarly, the frequency of northern producers that export their calves is greater in municipalities with lower poverty levels (Medium 8.1\%, Low 33.5\% and Very Low 30.9\%; sed = 4.9). In fact, cow-calf operations from the north region of Mexico have been heavily impacted by commercial exchange through the border, where American beef farmers have been buying Mexican produced calves for more than 150 years, with an average of 1.2 million animals placed annually. ${ }^{14}$ This international exchange has encouraged the adoption of sanitary campaigns in Mexico and the introduction of beef breeds 
Table 1. Proportion* of producers exclusively dedicated to the cattle herd, or with complementary activities, and observed differences according to productive purpose, climate and poverty level of the municipality.

\begin{tabular}{|c|c|c|c|c|c|}
\hline & \multicolumn{5}{|c|}{ Complementary activities } \\
\hline & $\begin{array}{c}\text { Cattle herd } \\
\text { exclusively }\end{array}$ & $\begin{array}{c}\text { Other } \\
\text { livestock }\end{array}$ & Crops & $\begin{array}{c}\text { Non-farm } \\
\text { employment }\end{array}$ & sed \\
\hline Population mean & 38.3 & 6.0 & 40.2 & 19.1 & 1 \\
\hline Productive purpose & & & & & $\mathbf{2 . 4}$ \\
\hline Beef & 40.9 & 6.1 & 37.6 & 19.5 & \\
\hline Dual purpose & 33.4 & 5.7 & 45.4 & 18.7 & \\
\hline Climate & & & & & 2.4 \\
\hline Arid and Semi-Arid & 32.8 & 6.1 & 42.8 & 21.6 & \\
\hline Temperate & 12.8 & 5.3 & 74.1 & 16.0 & \\
\hline Dry Tropic & 41.4 & 5.1 & 37.4 & 18.7 & \\
\hline Humid Tropic & 50.9 & 8.2 & 27.3 & 18.9 & \\
\hline Poverty level & & & & 2.8 \\
\hline Very low & 45.8 & 5.8 & 28.1 & 21.7 & \\
\hline Low & 34.0 & 6.3 & 45.7 & 17.1 & \\
\hline Medium & 39.5 & 4.3 & 40.0 & 18.9 & \\
\hline High & 37.8 & 11.4 & 36.5 & 22.6 & \\
\hline Very high & 32.3 & 2.5 & 54.9 & 14.5 & \\
\hline
\end{tabular}

* The sum of the proportions in a given row can differ from 100\%, since presented values correspond to minimum quadratic means and/or because more than one answer was possible.

of European origin, as well as the establishment of animal identification and traceability programs, such as the National Individual Livestock Identification System (SINIIGA) and the National Livestock Census (PGN), which have records for over 30 million animals in more than one million farms. ${ }^{15}$

The main commercial product of the cow-calf system is weaned calves (Table 2). Also, between 15\% and 35\% of farmers declared to background their calves before they are sent to feedlots and, 13\% of units finish their cattle. The latter is more common in operations located in temperate climates (24.9\%), which seems consistent with the higher proportion of production units found to raise crops in these areas. Marketing of breeding stock is more frequent in the arid and semi-arid climates, in the North region of the country, in large herds and in private properties (Table 2). As expected, milk or milk by-products were mostly absent in beef producing herds.

For product placement, both the national and international markets establish particular criteria, where males and smaller calves are usually more sought and consequently better paid. Similarly, the export market prefers animals with less Zebu but more Angus and Hereford traits or, to a lesser extent, with European continental breed characteristics. The domestic market on the other hand also favors European crossbred cattle over Zebu breeds, the price difference being capitalized by the middlemen. In fact, it is these middlemen who establish the traits and commercial criteria, their opinion being influential for the producer in terms of breed selection.

Breed prevalence varies according to the declared production purpose of the farm. European breeds crossed with Zebu cattle predominate in over 50\% of 
Table 2. Main commercial products of the farm, and observed frequencies in different productive purposes, climates, regions, herd sizes, and land tenure types (\% of cow-calf operations*).

\begin{tabular}{|c|c|c|c|c|c|c|}
\hline & \multicolumn{5}{|c|}{ Main Product } & \multirow[b]{2}{*}{ sed } \\
\hline & $\begin{array}{l}\text { Weaned } \\
\text { calves }\end{array}$ & Backgrounders & $\begin{array}{l}\text { Finished } \\
\text { animals }\end{array}$ & $\begin{array}{l}\text { Breeding } \\
\text { stock }\end{array}$ & $\begin{array}{c}\text { Dairy } \\
\text { products }\end{array}$ & \\
\hline Population mean & 85.0 & 20.4 & 13.0 & 5.7 & 22.1 & 1 \\
\hline Productive purpose & & & & & & 1.1 \\
\hline Beef & 86.0 & 24.2 & 16.1 & 6.7 & 0.9 & \\
\hline Dual purpose & 84.0 & 13.6 & 6.9 & 3.6 & 66.3 & \\
\hline Climate & & & & & & 1.9 \\
\hline Arid and Semi-Arid & 86.4 & 21.4 & 10.5 & 8.6 & 15.0 & \\
\hline Temperate & 72.2 & 34.9 & 24.9 & 7.5 & 16.4 & \\
\hline Dry Tropic & 90.0 & 15.9 & 14.2 & 4.3 & 24.0 & \\
\hline Humid Tropic & 76.8 & 25.2 & 8.0 & 4.3 & 30.3 & \\
\hline Region & & & & & & 1.9 \\
\hline North & 85.9 & 27.8 & 13.1 & 10.5 & 4.2 & \\
\hline Pacific & 59.8 & 17.6 & 13.3 & 5.2 & 36.8 & \\
\hline Center & 73.1 & 35.5 & 20.6 & 5.7 & 13.9 & \\
\hline Gulf & 89.8 & 11.2 & 3.8 & 5.0 & 30.9 & \\
\hline Peninsula & 87.5 & 19.7 & 19.7 & 2.0 & 5.9 & \\
\hline Herd Size & & & & & & 1.5 \\
\hline Small & 85.1 & 21.4 & 15.1 & 3.2 & 23.1 & \\
\hline Medium & 85.7 & 19.2 & 12.1 & 5.1 & 25.5 & \\
\hline Large & 84.0 & 20.4 & 10.4 & 11.6 & 15.0 & \\
\hline Land Tenure & & & & & & 1.7 \\
\hline Ejido & 91.4 & 15.6 & 8.9 & 2.9 & 24.0 & \\
\hline Communal & 83.1 & 25.2 & 19.8 & 2.9 & 14.1 & \\
\hline Private & 80.8 & 23.2 & 14.8 & 8.5 & 22.2 & \\
\hline
\end{tabular}

* The sum of the proportions in a given row can differ from 100\%, since presented values correspond to minimum quadratic means and/or because more than one answer was possible.

beef-producing units, followed by Bos taurus taurus animals (in just over 30\% of operations) (Table 3). Criollo and predominantly Zebu cattle are reported in less than $15 \%$ of operations, and pure or crossbred dairy animals are rarely seen $(<5 \%$ of beef cattle farms). In fact, Zebu cattle can be found in less than 10\% of all surveyed cow-calf operations at national level, except for the dry tropic areas and the Yucatan peninsula, where Zebu animals can be seen in 16\% and 26\% of the farms, respectively. European beef breeds predominate in herds of the North of Mexico $(>40 \%)$, which is also where most of the Criollo cattle are located (11.6\%). The percentage of operations that own cattle that is predominantly Zebu is twofold in small size herds, when compared to medium and large herds (Table 3). The presence of dairy cattle breeds or of dairy animals crossbred with Zebu is 10 fold greater in dual-purpose herds than in beef-cattle operations (table 3). The racial distribution for dual-purpose cattle is analyzed in an accompanying article. ${ }^{16}$

It seems that, especially over the past 50 years, the genetic structure of the beef and dual-purpose cattle population has changed in Mexico, with a marked 
Table 3. Breed prevalence, and observed frequencies according to productive purpose, climate, region and herd size (\% of cow-calf operations *).

\begin{tabular}{|c|c|c|c|c|c|c|c|}
\hline & $\begin{array}{c}\text { European } \\
\text { beef (B) }\end{array}$ & $\begin{array}{l}\text { European } \\
\text { dairy (D) }\end{array}$ & Zebu (Z) & Criollo & $\mathbf{B} \times \mathbf{Z}$ & DXZ & sed \\
\hline Population mean & 22.0 & 2.1 & 7.1 & 4.5 & 45.2 & 20.4 & 0.9 \\
\hline Productive purpose & & & & & & & 1.1 \\
\hline Beef & 30.1 & 0.5 & 9.3 & 4.9 & 52.3 & 4.2 & \\
\hline Climate & & & & & & & 2.2 \\
\hline Arid and Semi-Arid & 43.5 & 0.3 & 2.1 & 9.7 & 45.1 & 0.3 & \\
\hline Temperate & 34.6 & 1.1 & 6.1 & 7.3 & 51.4 & 1.7 & \\
\hline Dry Tropic & 26.3 & 0.4 & 15.6 & 2.7 & 51.4 & 4.7 & \\
\hline Humid Tropic & 16.2 & 0.6 & 5.2 & 2.0 & 67.3 & 11.8 & \\
\hline Region & & & & & & & 2.1 \\
\hline North & 42.4 & 0.2 & 0.2 & 11.6 & 46.6 & 0.0 & \\
\hline Pacific & 19.9 & 1.1 & 10.5 & 3.7 & 64.4 & 3.0 & \\
\hline Center & 31.3 & 1.2 & 6.0 & 6.3 & 53.6 & 4.2 & \\
\hline Gulf & 40.1 & 0.0 & 5.3 & 2.0 & 42.9 & 10.1 & \\
\hline Peninsula & 13.5 & 0.0 & 26.5 & 0.5 & 55.4 & 3.7 & \\
\hline Herd Size & & & & & & & 1.7 \\
\hline Small & 25.3 & 0.8 & 13.1 & 4.3 & 50.3 & 6.3 & \\
\hline Medium & 29.2 & 0.2 & 8.0 & 2.9 & 56.4 & 3.8 & \\
\hline Large & 39.0 & 0.4 & 4.6 & 8.5 & 49.8 & 1.5 & \\
\hline
\end{tabular}

* The sum of the proportions in a given row can differ from 100\%, since presented values correspond to minimum quadratic means and/or because more than one answer was possible.

** Note: The distribution of the racial type for dual purpose operations is presented in an accompanying paper.

tendency to decrease the Criollo and the Zebu biotypes. In fact, even if the genetic base of cattle continues to comprise crossbred animals with a varying input of Zebu breeds, a higher proportion of European crosses can be now seen in beef cattle farms. There is, however, no official or detailed information to quantify this transformation, and barely a few certified documents can be used as a general reference. For instance, the 1977-1982 Livestock National Plan ${ }^{17}$ reported that the Criollo and Zebu biotypes were prevalent in 57\% and 29.2\% of the grazing cattle population. It is noteworthy that both biotypes were found jointly in less than $12 \%$ of farms included in this study (Table 3). The reported racial structure for cattle in the Agricultural Census of 2007, ${ }^{18}$ was closer to the findings of this survey; with $15.9 \%$ of the animals classified as having a non-defined breed, 57\% as crossbred, and nearly $31 \%$ as purebred. The observed changes in breed distribution overtime in Mexico are undoubtedly the result of decades of ongoing government programs, which have supported the acquisition of purebred bulls, and the implementation of artificial insemination. Consequently, there has been an erosion of the Criollo gene pool, which may relate to differences in productive parameters such as lower growth rates for Zebu and Criollo than for European breeds and their crossbreeds. ${ }^{18}$

Producers surveyed in this study declared to select the breed of their cattle primarily based on productive characteristics ( $\approx 50 \%)$; adaptability $(\approx 25 \%)$ and personal preference $(\approx 20 \%)$ (Table 4$)$. Market demand was stated as important for $7 \%$ of farmers. Land tenure, herd size and poverty level did not affect the selection 
Table 4. Breed selection criteria, and observed frequencies according to productive purpose, climate and region (\% of cow-calf operations *).

\begin{tabular}{|c|c|c|c|c|c|c|c|}
\hline & $\begin{array}{l}\text { Productive } \\
\text { Traits }\end{array}$ & Adaptability & $\begin{array}{l}\text { Personal } \\
\text { reference }\end{array}$ & $\begin{array}{l}\text { Market } \\
\text { Demand }\end{array}$ & $\begin{array}{l}\text { Technical } \\
\text { advice }\end{array}$ & $\begin{array}{l}\text { Does not } \\
\text { select }\end{array}$ & sed \\
\hline Population mean & 49.6 & 25.8 & 19.8 & 7.2 & 1.6 & 2.7 & 0.9 \\
\hline Productive purpose & & & & & & & 1.3 \\
\hline Beef & 45.2 & 28.2 & 20.6 & 7.9 & 1.7 & 2.7 & \\
\hline Dual Purpose & 58.5 & 21.2 & 17.7 & 5.9 & 1.2 & 3.0 & \\
\hline Climate & & & & & & & 2.0 \\
\hline Arid and Semi-Arid & 44.4 & 30.3 & 16.7 & 7.6 & 3.0 & 4.4 & \\
\hline Temperate & 53.2 & 23.4 & 20.2 & 3.5 & 1.4 & 1.1 & \\
\hline Dry Tropic & 49.6 & 24.6 & 21.7 & 8.4 & 1.1 & 2.4 & \\
\hline Humid Tropic & 54.9 & 24.6 & 17.9 & 5.9 & 0.9 & 2.6 & \\
\hline Region & & & & & & & 2.0 \\
\hline North & 44.6 & 27.4 & 17.3 & 10.7 & 1.6 & 5.0 & \\
\hline Pacific & 56.1 & 23.2 & 19.4 & 6.9 & 2.0 & 2.9 & \\
\hline Center & 44.3 & 37.9 & 16.3 & 4.8 & 1.3 & 2.3 & \\
\hline Gulf & 47.8 & 25.0 & 16.6 & 7.2 & 1.8 & 2.5 & \\
\hline Peninsula & 49.9 & 17.9 & 32.2 & 6.9 & 0.5 & 0.7 & \\
\hline
\end{tabular}

* The sum of the proportions in a given row can differ from $100 \%$, since presented values correspond to minimum quadratic means and/or because more than one answer was possible.

criteria. Recommendations from specialists were considered by less than 2\% of farmers as a decisive factor for breed selection, a percentage which was similar to that of producers who declared not making any selection at all (3\%) (Table 4). The animals' breed adaptability to its environment is more frequently considered as an important factor for breed selection by farmers of arid and semi-arid climates (30.3\%). In the Yucatan Peninsula, more than 30\% of the producers stated personal preference as the leading factor for choosing the breed. In fact, personal preference was the main selection criterion for one of five producers nationwide. Interestingly, over 70\% of farmers reported to select the breed based on productive and adaptability traits. However, in a setting where in-farm record-keeping is deficient, this information must be adopted from outside sources. In any case, since there is a high demand for beef animals, and an extensive supply by the producers, market preferences are a minor criterion for the farmers when selecting their breeding stock. Ultimately, it is the middlemen who establish the purchasing price and, animals that have a greater value are those that meet the characteristics favored by the final buyers, who generally prefer European breeds.

It should be expected for cow-calf rearing systems to consider growth rate and other productive traits of calves as important criteria for breed selection. However, this would entail proper record-keeping which was deficient in the surveyed operations included in this study. In fact, close to half of the farms do not keep records at all (Table 5). Still, in production units where records are kept, the registered events in order of importance are reproductive (59.1\%), calf data (44\%), herd health practices (32\%), and sales and purchases (28\%) (table 5). Also, record-keeping is less frequent in ejidos, in communal farms and in small herds than in private and large production units. The most common method to register data is the hand-written 
Table 5. Frequency of record keeping and preferred record format, and observed frequencies according to productive purpose, herd size, land tenure type and poverty level (\% of cow-calf operations *).

\begin{tabular}{|c|c|c|c|c|}
\hline & \multicolumn{4}{|c|}{ Record-keeping format } \\
\hline & $\begin{array}{l}\text { Does not keep } \\
\text { records }\end{array}$ & Hand-written & Computer & sed \\
\hline Population Mean & 47.4 & 47.3 & 6.4 & 0.9 \\
\hline \multicolumn{5}{|l|}{ Productive purpose } \\
\hline Beef & 46.7 & 47.2 & 8.0 & \\
\hline Dual Purpose & 49.1 & 47.7 & 2.8 & \\
\hline sed & 1.9 & 1.9 & 0.9 & \\
\hline \multicolumn{5}{|l|}{ Herd Size } \\
\hline Small & 52.1 & 44.5 & 2.1 & \\
\hline Medium & 47.8 & 48.5 & 5.1 & \\
\hline Large & 37.7 & 51.0 & 16.5 & \\
\hline sed & 2.3 & 2.3 & 1.1 & \\
\hline \multicolumn{5}{|l|}{ Land Tenure } \\
\hline Ejido & 57.8 & 39.4 & 1.8 & \\
\hline Communal & 56.9 & 37.7 & 4.5 & \\
\hline Private & 37.5 & 55.2 & 10.2 & \\
\hline sed & 2.7 & 2.7 & 1.3 & \\
\hline \multicolumn{5}{|l|}{ Poverty level } \\
\hline Very Low & 44.3 & 51.3 & 10.7 & \\
\hline Low & 45.7 & 46.3 & 9.7 & \\
\hline Medium & 47.7 & 47.6 & 4.9 & \\
\hline High & 47.9 & 47.0 & 6.2 & \\
\hline Very High & 54.0 & 43.4 & 0.8 & \\
\hline sed & 3.6 & 3.4 & 1.6 & \\
\hline
\end{tabular}

* The sum of the proportions in a given row can differ from 100\%, since presented values correspond to minimum quadratic means and/or because more than one answer was possible.

form (47.3\%). The use of computers is rare (6.4\%), but less limited in large and in privately-owned operations, located in municipalities with low and very low poverty levels (sed $=2$ ). Thus, it seems that as herds get smaller, the producers have less economic and/or technical resources, which leads them to rely more on memory recollection and less on formal records. In addition, the use of computers is higher among young producers (according to age, when they are in their 20's: 16.7\%; 30's: 9.0\%; 40's: 6.7\%; 50 years and older: $<6.6 \%$; sed=2.5).

An essential aspect for herd management, record keeping and farm organization is animal identification. Over $95.6 \%$ of the surveyed producers declared using some means of identification (Table 6). By far, the most frequent systems are hotiron marks and ear tags from the SINIIGA, which are normally employed jointly. The use of various other types of ear tags follow as chosen method, while cold marks are very rarely used (Table 6). It is worth noting that SINIIGA identification became compulsory for cattle in Mexico after this study ended, thus numbers of cattle identified with this method have continued to grow, with 11 million animals tagged in the last year only. ${ }^{19}$ The high frequency of hot iron branding found nationwide 
Table 6. Percentage of cow-calf operations* that identify all animals and method used, and observed frequencies according to productive purpose.

\begin{tabular}{|c|c|c|c|c|c|c|c|}
\hline & $\begin{array}{l}\text { Identifies } \\
\text { all cattle }\end{array}$ & Hot iron & SINIIGA** & Ear tags & Cold Iron & Other & sed \\
\hline Population Mean & 95.6 & 77.7 & 73.7 & 14.6 & 1.2 & 2.5 & 0.8 \\
\hline \multicolumn{8}{|l|}{ Productive purpose } \\
\hline Beef & 96.1 & 78.0 & 72.3 & 13.9 & 1.2 & 2.2 & \\
\hline Dual Purpose & 96.5 & 71.1 & 75.0 & 16.4 & 1.1 & 3.3 & \\
\hline sed & 0.6 & 1.6 & 1.7 & 1.4 & 0.4 & 0.6 & \\
\hline
\end{tabular}

* The sum of the proportions in a given row can differ from 100\%, since presented values correspond to minimum quadratic means and/or because more than one answer was possible.

**National Individual Livestock Identification System

may also relate to it being a deeply rooted traditional method to claim ownership of the cattle.

Regarding general infrastructure for animal management, close to $93 \%$ of the cow-calf operations in the country have a corral, with lower percentages observed in areas with temperate climate. Mechanical equipment, such as holding chutes are present in one third of farms, with lower observed frequencies in tropical climate regions. Over $40 \%$ of producers declared not to have loading ramps, which are important for cattle transport, since handling is safer and less stressful for the animals. Loading ramps are more frequent in operations bound to move more animals, such as those located in the North of the country, the Gulf and the Peninsula. The occurrence of ramps is also higher, in privately owned land, in municipalities with lower poverty level, in larger herds and in beef production units. Immersion baths for ectoparasite control exist in less than $20 \%$ of farms, and they are more common in areas where export activities are important, such as those located in the arid and semi-arid zones of the North region, in municipalities with low and very low poverty levels, in larger herds, in privately owned land, and in operations specialized in beef production. Regarding weight scales for cattle, barely one fifth of the surveyed properties declared having this equipment, with a similar distribution to the one described for immersion baths (Table 7). The somewhat higher frequencies of particular equipment in operations of the North of Mexico, may relate to an increased need of producers to adopt management practices, infrastructure and technology, commonly used in the United States.

In general, the limited presence of equipment, such as holding chutes and ramps, which should be found at least with the same frequency as corrals, may in part bear witness to the scarcity of resources and the low permeation of appropriate management practices. However, a recurring statement among producers is that the presence of loading ramps facilitates cattle rustling. As for the low occurrence of immersion baths, it may be an indication of a shift in methods for ectoparasite control toward techniques such as spraying and pouring on. Alternatively, it can also reflect the low compliance of cattle transport requirements established by the official Boophilus tick control campaign, at least for shipments near the farm. However, when cattle are transported greater distances to reach feedlots, treatments against ectoparasites are applied in collective gathering pens. Hence, in-farm immersion baths may be redundant. Similarly, the low percentage of operations having weight scales may denote lack of market stimuli to determine the productive performance 
Table 7. Frequency of occurrence* of infrastructure in cow-calf production units, and observed differences according to productive purpose, climate, region, herd size, land tenure type and poverty level of the municipality.

\begin{tabular}{|c|c|c|c|c|c|c|c|}
\hline & Irrigation & Corral & Holding chute & Loading ramp & Immersion bath & Scale & sed \\
\hline Population Mean & 12.7 & 93.3 & 27.6 & 55.3 & 16.6 & 19.4 & 1.0 \\
\hline \multicolumn{8}{|l|}{ Productive purpose } \\
\hline Beef & 11.9 & 93.4 & 30.7 & 61.6 & 20.8 & 23.0 & \\
\hline Dual Purpose & 14.2 & 93.5 & 22.6 & 42.3 & 8.2 & 11.5 & \\
\hline sed & 1.3 & 0.9 & 1.7 & 1.9 & 1.4 & 1.5 & \\
\hline \multicolumn{8}{|l|}{ Climate } \\
\hline Arid and Semi-Arid & 16.5 & 96.1 & 40.9 & 60.3 & 27.8 & 31.1 & \\
\hline Temperate & 8.5 & 82.3 & 42.4 & 47.3 & 13.5 & 15.6 & \\
\hline Dry Tropic & 14.2 & 92.6 & 18.6 & 58.7 & 12.4 & 16.1 & \\
\hline Humid Tropic & 5.9 & 97.6 & 27.6 & 43.9 & 14.8 & 13.5 & \\
\hline sed & 2.0 & 1.4 & 2.6 & 2.9 & 2.2 & 2.3 & \\
\hline \multicolumn{8}{|l|}{ Region } \\
\hline North & 12.9 & 94.6 & 51.0 & 73.8 & 34.9 & 37.7 & \\
\hline Pacific & 15.9 & 91.2 & 24.1 & 32.1 & 10.3 & 11.4 & \\
\hline Central & 9.2 & 87.2 & 41.2 & 46.4 & 11.1 & 14.4 & \\
\hline Gulf & 8.7 & 97.2 & 18.8 & 60.8 & 22.4 & 25.5 & \\
\hline Peninsula & 15.7 & 98.0 & 9.3 & 87.7 & 5.9 & 9.8 & \\
\hline sed & 2.0 & 1.4 & 2.6 & 2.7 & 2.1 & 2.3 & \\
\hline \multicolumn{8}{|l|}{ Herd Size } \\
\hline Small & 12.1 & 91.3 & 19.4 & 42.3 & 6.2 & 7.3 & \\
\hline Medium & 12.7 & 94.1 & 27.5 & 58.9 & 14.1 & 17.5 & \\
\hline Large & 13.1 & 96.1 & 43.7 & 76.6 & 40.8 & 45.9 & \\
\hline sed & 1.5 & 1.2 & 2.0 & 2.2 & 1.6 & 1.7 & \\
\hline \multicolumn{8}{|l|}{ Land Tenure } \\
\hline Ejido & 14.4 & 92.2 & 17.9 & 47.3 & 10.7 & 11.4 & \\
\hline Communal & 7.7 & 95.2 & 10.9 & 51.1 & 4.5 & 8.6 & \\
\hline Private & 12.2 & 93.7 & 38.5 & 62.6 & 23.7 & 27.8 & \\
\hline sed & 1.8 & 1.4 & 2.4 & 2.7 & 2.0 & 2.1 & \\
\hline \multicolumn{8}{|l|}{ Poverty level } \\
\hline Very Low & 13.3 & 95.1 & 49.3 & 61.2 & 24.9 & 33.6 & \\
\hline Low & 17.5 & 94.5 & 35.0 & 62.4 & 25.4 & 28.5 & \\
\hline Medium & 14.1 & 92.8 & 23.0 & 57.1 & 15.6 & 16.9 & \\
\hline High & 6.2 & 93.2 & 22.7 & 50.8 & 9.5 & 10.5 & \\
\hline Very High & 7.2 & 93.6 & 23.0 & 30.2 & 8.1 & 12.3 & \\
\hline sed & 2.3 & 1.7 & 3.0 & 3.3 & 2.5 & 2.6 & \\
\hline
\end{tabular}

* The sum of the proportions in a given row can differ from 100\%, since presented values correspond to minimum quadratic means and/or because more than one answer was possible. 
of the herd; especially considering that weaning calves are their main selling product. Occurrence of loading ramps and mechanical equipment (holding chutes and scales) is higher in units specialized in beef production when compared to dual purpose cattle (Table 7). This difference in the adoption of infrastructure possibly relates to the fact that beef cattle are less frequently handled, whereas dual-purpose cattle are used to daily management practices, are generally tamer and need simpler infrastructure to be controlled.

Presence of an irrigation structure is generally scarce in cow-calf operations (less than 17\%). Nonetheless, it is more frequent in cow-calf production units located in arid and semi-arid areas of Mexico, as well as in the dry tropics, particularly from the North, Pacific and Peninsula regions. There were no observed differences regarding presence of irrigation linked to herd size or land-tenure type. Operations placed in municipalities with high and very high poverty levels have less access to irrigation than those located in municipalities of medium to very low poverty levels. In fact, there are roughly twice as many farms with this infrastructure in the latter group than there are in the former (Table 7).

An essential aspect to improve any commercial business is to periodically update production processes through technical guidance. However, close to 32\% of the producers declared never to receive technical advice, with nearly $20 \%$ relying entirely on their own experience. When technical assistance is requested, it is mainly provided by independent professionals (30\%), followed by livestock owners associations and by other producers (12.6\%, Table 8$)$. Interestingly, government institutions have very low input in advising producers $(<2 \%)$; nonetheless, the methodology of Livestock Support Groups for Validation and Transfer of Technology (GGAVATT), is recognized by $6 \%$ of ranchers as a source for technical information. As a trend, technical assistance was less sought in the tropics and in communal land and ejidos. Technical guidance through livestock associations was demanded more frequently in temperate climate and in the central region of Mexico. Independent professional advice was requested more frequently in operations with large herds and in private property. Interestingly, the internet, printed publications, TV and radio were jointly regarded as information sources by less than $2 \%$ of farmers (Table 8). Technical assistance was more often provided on preventive medicine (40.1\%) and reproductive management (17.7\%); followed by pasture management and nutrition (15.6\%) and lastly, genetics (12.4\%)(sed = 1). In general, operations with large herds, in private property or specialized in dual purpose cattle received more technical advice than farms with smaller herds, located in ejidos or communal land, or specialized in beef production.

It is important to consider that the distribution of cow-calf operations throughout the country, as well as the large amount of producers and the number of animals per herd represent a challenge for the establishment of an efficient technical support system. This study shows that only half of the farms get external assistance, and that it is mostly given by independent professionals, probably due to the need to deal with emergencies that entail possible animal losses. Producers generally associate technical guidance with prevention and treatments, since mandatory compliance of specific health management practices is imposed in order to avoid sanctions such as quarantines or restrictions on product marketing. Animal health (unlike other technical areas) has permanent bodies financed by public funds in every state of the country, which comprise the Animal Protection and Develop- 
Table 8. Sources of technical assistance sought by producers, and differences according to productive purpose, climate, region, herd size, land tenure type and poverty level of the municipality (\% of cow-calf operations *).

\begin{tabular}{|c|c|c|c|c|c|c|c|c|}
\hline & None & $\begin{array}{l}\text { Personal } \\
\text { experience }\end{array}$ & $\begin{array}{l}\text { Independent } \\
\text { Professional }\end{array}$ & GGAVATT'a & $\begin{array}{l}\text { Livestock } \\
\text { Association } \\
\text { and other } \\
\text { producers }\end{array}$ & Institution** & Other*** & sed \\
\hline Population Mean & 32.3 & 20.4 & 30.0 & 6.4 & 12.6 & 1.1 & 1.4 & 0.7 \\
\hline $\begin{array}{l}\text { Productive } \\
\text { purpose }\end{array}$ & & & & & & & & 1.0 \\
\hline Beef & 33.7 & 21.9 & 30.2 & 3.5 & 11.1 & 1.4 & 2.9 & \\
\hline Dual Purpose & 29.5 & 17.5 & 29.6 & 12.6 & 15.6 & 1.0 & 2.0 & \\
\hline Climate & & & & & & & & 1.5 \\
\hline Arid and Semi-Arid & 26.0 & 23.2 & 26.6 & 13.0 & 14.1 & 0.9 & 3.2 & \\
\hline Temperate & 25.9 & 22.7 & 21.3 & 2.8 & 26.2 & 3.5 & 3.2 & \\
\hline Dry Tropic & 35.2 & 19.7 & 32.2 & 4.5 & 10.6 & 0.9 & 2.5 & \\
\hline Humid Tropic & 36.6 & 17.7 & 33.5 & 4.3 & 9.0 & 0.7 & 1.9 & \\
\hline Region & & & & & & & & 1.5 \\
\hline North & 25.0 & 29.8 & 27.2 & 5.0 & 16.5 & 1.2 & 5.6 & \\
\hline Pacific & 24.8 & 27.4 & 28.6 & 14.4 & 9.7 & 0.5 & 1.4 & \\
\hline Central & 22.8 & 21.8 & 35.1 & 1.3 & 21.1 & 2.5 & 2.5 & \\
\hline Gulf & 55.2 & 3.0 & 25.4 & 4.1 & 12.0 & 0.7 & 1.7 & \\
\hline Peninsula & 30.5 & 21.6 & 39.1 & 0.0 & 5.6 & 1.5 & 4.4 & \\
\hline Herd Size & & & & & & & & 1.2 \\
\hline Small & 34.2 & 22.7 & 26.1 & 6.5 & 11.5 & 0.8 & 1.0 & \\
\hline Medium & 34.8 & 20.8 & 25.8 & 7.9 & 12.6 & 1.4 & 1.2 & \\
\hline Large & 27.5 & 14.0 & 42.8 & 4.5 & 13.7 & 1.3 & 2.2 & \\
\hline Land Tenure & & & & & & & & 1.4 \\
\hline Ejido & 40.9 & 18.7 & 25.7 & 6.9 & 10.4 & 0.9 & 0.6 & \\
\hline Communal & 32.9 & 14.8 & 29.7 & 5.1 & 12.1 & 1.0 & 0.6 & \\
\hline Private & 26.5 & 22.3 & 33.0 & 6.4 & 13.9 & 1.4 & 2.0 & \\
\hline
\end{tabular}

* The sum of the proportions in a given row can differ from $100 \%$, since presented values correspond to minimum quadratic means and/or because more than one answer was possible. / **Universities and INIFAP / *** Vendors, radio, TV, internet and printed publications. aLivestock Support Groups for Validation and Transfer of Technology

ment Committees, that operate basically by producer organizations in support of governmental health campaigns. This agrees with the producer's perception that advice from these organizations may be of benefit for them. Advice in areas related to herd productivity and use of natural resources is less frequent, with a very low contribution from academic and government institutions. The GGAVATT, has a larger presence for dual-purpose cattle, and for small and medium-sized herds, which are the types of operations for which it was conceived. It is however imperative for the improvement of cattle operations that relevant information reaches the producers. This stresses the need to develop extension programs that will permeate throughout agro-ecological regions and strata of farm owners. In addition, methodologies should be tailored for areas with more difficulties and higher potential, as is the case for the humid and dry tropics, which comprise more than 50\% of the cow-calf operations in Mexico. Moreover, 84\% of tropical operations have herds of less than 
Table 8. Sources of technical assistance sought by producers, and differences according to productive purpose, climate, region, herd size, land tenure type and poverty level of the municipality (\% of cow-calf operations *).

\begin{tabular}{|c|c|c|c|c|c|c|c|c|}
\hline & None & $\begin{array}{l}\text { Personal } \\
\text { experience }\end{array}$ & $\begin{array}{l}\text { Independent } \\
\text { Professional }\end{array}$ & GGAVATTa & $\begin{array}{l}\text { Livestock } \\
\text { Association } \\
\text { and other } \\
\text { producers }\end{array}$ & Institution** & Other*** & sed \\
\hline Population Mean & 32.3 & 20.4 & 30.0 & 6.4 & 12.6 & 1.1 & 1.4 & 0.7 \\
\hline $\begin{array}{l}\text { Productive } \\
\text { purpose }\end{array}$ & & & & & & & & 1.0 \\
\hline Beef & 33.7 & 21.9 & 30.2 & 3.5 & 11.1 & 1.4 & 2.9 & \\
\hline Dual Purpose & 29.5 & 17.5 & 29.6 & 12.6 & 15.6 & 1.0 & 2.0 & \\
\hline Climate & & & & & & & & 1.5 \\
\hline Arid and Semi-Arid & 26.0 & 23.2 & 26.6 & 13.0 & 14.1 & 0.9 & 3.2 & \\
\hline Temperate & 25.9 & 22.7 & 21.3 & 2.8 & 26.2 & 3.5 & 3.2 & \\
\hline Dry Tropic & 35.2 & 19.7 & 32.2 & 4.5 & 10.6 & 0.9 & 2.5 & \\
\hline Humid Tropic & 36.6 & 17.7 & 33.5 & 4.3 & 9.0 & 0.7 & 1.9 & \\
\hline Region & & & & & & & & 1.5 \\
\hline North & 25.0 & 29.8 & 27.2 & 5.0 & 16.5 & 1.2 & 5.6 & \\
\hline Pacific & 24.8 & 27.4 & 28.6 & 14.4 & 9.7 & 0.5 & 1.4 & \\
\hline Central & 22.8 & 21.8 & 35.1 & 1.3 & 21.1 & 2.5 & 2.5 & \\
\hline Gulf & 55.2 & 3.0 & 25.4 & 4.1 & 12.0 & 0.7 & 1.7 & \\
\hline Peninsula & 30.5 & 21.6 & 39.1 & 0.0 & 5.6 & 1.5 & 4.4 & \\
\hline Herd Size & & & & & & & & 1.2 \\
\hline Small & 34.2 & 22.7 & 26.1 & 6.5 & 11.5 & 0.8 & 1.0 & \\
\hline Medium & 34.8 & 20.8 & 25.8 & 7.9 & 12.6 & 1.4 & 1.2 & \\
\hline Large & 27.5 & 14.0 & 42.8 & 4.5 & 13.7 & 1.3 & 2.2 & \\
\hline Land Tenure & & & & & & & & 1.4 \\
\hline Ejido & 40.9 & 18.7 & 25.7 & 6.9 & 10.4 & 0.9 & 0.6 & \\
\hline Communal & 32.9 & 14.8 & 29.7 & 5.1 & 12.1 & 1.0 & 0.6 & \\
\hline Private & 26.5 & 22.3 & 33.0 & 6.4 & 13.9 & 1.4 & 2.0 & \\
\hline
\end{tabular}

* The sum of the proportions in a given row can differ from $100 \%$, since presented values correspond to minimum quadratic means and/or because more than one answer was possible. / **Universities and INIFAP / *** Vendors, radio, TV, internet and printed publications. aLivestock Support Groups for Validation and Transfer of Technology

37 cows that jointly encompass over $45 \%$ of the cattle present in the tropics. 15,20 On the other hand, $80 \%$ of the forage biomass of the country is produced in grazing areas in the tropics. ${ }^{21,22}$ It is also in the tropics where the highest potential to increase pasture-based animal production exists, ${ }^{21}$ and where diversification of ecosystem services is more promising. ${ }^{23}$

Finally, when producers were asked to rank the factors limiting growth and profitability of their operations, lack of credit and cash flow came as the most important issue, followed by low market price of their products and lack of in-farm infrastructure. Marketing channels and product demand were declared as less important and access to highways and roads was reported as a minor cause (Table 9). It should be noted however that as a rule, set prices paid to the primary producer of medium and small sized operations are subsequently inflated by redundant middlemen. Access to financial liquidity is also restricted for smaller operations, 
Table 9. Factors limiting growth and profitability of cow-calf operations*.

\begin{tabular}{|c|c|c|c|c|c|c|c|}
\hline & $\begin{array}{c}\text { Credit and } \\
\text { cash flow }\end{array}$ & $\begin{array}{c}\text { Price of } \\
\text { products }\end{array}$ & $\begin{array}{c}\text { Farm } \\
\text { Infrastructure }\end{array}$ & $\begin{array}{c}\text { Marketing } \\
\text { channels }\end{array}$ & $\begin{array}{c}\text { Product } \\
\text { demand }\end{array}$ & $\begin{array}{c}\text { Communication } \\
\text { channels }\end{array}$ & sed \\
\hline Population Mean & 9 & 8.1 & 7.9 & 7.2 & 7 & 6.5 & 0.04 \\
\hline Productive purpose & & & & & & & 0.06 \\
\hline Beef & 9.1 & 8.1 & 7.9 & 7.3 & 7.0 & 6.4 & \\
\hline Dual Purpose & 9.0 & 8.2 & 7.8 & 7.1 & 7.0 & 6.7 \\
\hline
\end{tabular}

* The rating was awarded on a scale of 5 to 10 , where 10 represents the most important resource.

since they are unattractive to the private banking systems. This highlights the need to develop new approaches to activate low amount credits, with accessible guarantees and settlement periods that are agreeable with the extended production cycles distinctive of cow-calf operations. Fittingly, some of these considerations are being included in public policies of the current government. Furthermore, producer unions are presented with a great area of opportunity to provide assistance concerning microeconomic everyday decision management to small operation owners.

\section{Conclusions and implications}

This study highlights important areas of opportunity for cow-calf systems in Mexico. The use and layout of in-farm records dictate the organization, animal flow and economic management of the production unit. Our data show that only half of the producers keep records, and reproductive and calf data are the main registered events. Both record-keeping and associated registered events need to expand and further include variables inherent to the production system, to provide necessary information for sound and profitable decision-making. For instance, under the present circumstances, close to 55\% of farmers select their cattle based on non-productive parameters. Fortunately, record systems could build on successful programs such as SINIIGA, which has achieved extended coverage throughout the country; also providing a great opportunity for government agencies and local breeder associations to promote and showcase the individual and collective benefits of record keeping.

Technical assistance from external sources was found to be sought by less than half of the surveyed producers. This may partially stem from the fact that cattle breeding remains a deeply traditional activity in Mexico, where most producers grew up learning management practices that have remained virtually unchanged for generations. Also, there is little use of printed media, massive media outlets and internet to seek for relevant farming information. In fact, producers mainly request technical advice from independent professionals and fellow farmers. Nonetheless, the improvement of cattle operations warrants a periodical flow of pertinent and updated information that is needed for sound and profitable decision making. Development of extension programs that permeate throughout agro-ecological regions and strata of farm owners is thus imperative to improve productivity and sustainability. In addition, methodologies should be tailored for areas with more difficulties and a higher potential. Finally, lack of credit and low cash flow were perceived as the most important factors limiting growth and profitability of calf-cow 
operations in Mexico. The development of credit programs that care for this niche is thus paramount.

\section{Funding}

This research was supported by SAGARPA, Mexico, projectNo. 32239-1463-2-VIII-12.

\section{Acknowledgements}

Authors wish to thank all professional personnel that administered the questionnaires and captured data.

\section{Conflicts of interest}

The authors declare no conflicts of interest.

\section{Author contributions}

E.G.P.: experimental design, manuscript drafting, discussion and preparation of the final document; C.G.: questionnaire and experimental design, project management, statistical analyses, discussion and preparation of the final document; A.L.: experimental design, project management, data capture, statistical analyses, discussion and preparation of the final document; M.P.: questionnaire and experimental design.

\section{References}

1. González-Padilla E, Magaña-Virgen M, Contreras-Rodríguez S, Valencia- Salazar E. Superficies dedicadas a la ganadería en México: su aportación de energía metabolizable actual y potencial, carga animal y balances energéticos para rumiantes domésticos y equinos por zonas y entidades. Anales de la Academia Veterinaria Mexicana. 1980;23-57.

2. Estadísticas del Medio Ambiente, México 1994. $1^{\text {a }}$ ed. México: Instituto Nacional de Estadística Geografía e informática; 1995.

3. Villegas Durán G, Bolaños Medina A, Olguín Prado L. La ganadería en México. $1^{\text {a }}$ ed. México: Instituto de Geografía, UNAM, Plaza y Valdés; 2001.

4. Livestock on grazing lands. FAO. 2014. Available from: www.fao.org/docrep/ x5304e/x5304e03.htm.

5. Panunzi E. Are grasslands under threat? Brief analysis of FAO statistical data on pasture and fodder crops. FAO; 2008. Available from: http://www.fao.org/ag/ portal/agp/agp-news/detail/en/c/6896/_

6. Alcázar Godoy J. Ley Agraria de 1915 y Ley Agraria vigente: modelos paralelos de tenencia de la tierra. Estudios Agrarios. Revista de la Procuraduría Agraria, 2016;61:161-92.

7. Beef 2007-08. Beef Cow-calf Management Practices in the United States, 2008. USDA, Available from: https://www.aphis.usda.gov/aphis/ourfocus/animalhealth/monitoring-and-surveillance/nahms/nahms_beef_cowcalf_studies

8. Padrón de beneficiarios PROGAN 2009. SAGARPA. Available from: https:// www.google.com/search?q=progan+2009\&rlz=1C1CHBD_esMX767MX$767 \&$ oq=progan $+2009 \&$ aqs=chrome..69i57.10199j0j4\&sourceid=chrome\&ie=UTF-8\# 
9. VSN International. Genstat for Windows. 19th ed. Hemel Hempstead: VSN International; 2017.

10. García E. Modificaciones al Sistema de clasificación climática de Koppen. $5^{a}$ ed. México: Instituto de Geografía, UNAM; 2004.

11. Índice de marginación municipal. Consejo Nacional de Población, 2013. Available from: http://www.conapo.gob.mx/es/CONAPO/ Indices_de_Marginacion_Publicaciones

12. Encuesta Nacional de Ocupación y Empleo (ENOE), población de 15 años y más de edad. INEGI, 2012. Available from: http://www.beta.inegi.org.mx/ proyectos/enchogares/regulares/enoe/

13. Diagnóstico del sector rural y pesquero. SAGARPA- FAO. 2012. Available from: http://www.fao.org/3/a-bc980s.pdf

14. SIAP-SAGARPA. 2018. Estadísticas Agropecuarias. Available from: https://www. gob.mx/cms/uploads/attachment/file/392425/Serie_Hist_rica_exportaci_n_ de_Bovinos_agosto-_2018.pdf

15. Padrón Ganadero Nacional (PGN) 2018. SAGARPA-CNOG. Available from: http://www.pgn.org.mx/_documents/EstadisticaPGNBovinos.pdf

16. Alonso-Díaz MA, Corro-Morales MD, Lassala A, González-Padilla E, Gutiérrez CG. Cow-calf management practices in Mexico: Dual-purpose systems [unpublished].

17. SARH-México. Plan Nacional Ganadero 1976-1982. México: SARH; 1977.

18. Roman Ponce $S$, Ríos Utrera A, Montaño Bermúdez M, Garcia Ruiz A, Sifuentes Rincón AM, Martínez Velázquez $G$, et al. Mejoramiento genético de los bovinos del trópico. En: Estado del arte sobre investigación e innovación tecnológica en ganadería bovina tropical. Capítulo 4. $2^{\mathrm{a}}$ ed. México: Red de Ganadería Tropical, UNAM, INIFAP. CONACYT; 2018. p. 130-92.

19. Informe de actividades 2018-2019 del Consejo Directivo de la Confederación Nacional de Organizaciones Ganaderas a la LXXXIII Asamblea General Ordinaria, Oaxaca, Oax. México. p. 17. May, 2019. Available from: www.cnog.org.mx

20. VIII Censo Nacional Agropecuario, Ganadero y Forestal 2007. INEGI. 2009. Available from: http://www.inegi.org.mx/est/contenidos/proyectos/Agro/ca2007/ resultados_agricola/presentacion.aspx

21. Programa Nacional de fomento a la producción sostenible de forrajes. SAGAR, INIFAP produce. September, 1996. México.

22. González-Padilla E. Animal production in México: Constraints, problems and researchable topics. Livestock Regional Assessment Workshop, IICA- SR- CRSP; 1997. p. 15-8.

23. González Rebeles C, Palma Garcia JM, Silva Cassani N, Gómez Fuentes T, Galindo Maldonado F. Recursos naturales y ganadería en el trópico. En: Estado del arte sobre investigación e innovación tecnologica en ganadería bovina tropical. Capítulo 1. $2^{\text {a }}$ ed. México: Red de Ganadería Tropical, UNAM, INIFAP. CONACYT; 2018. p. 44-58. 